\title{
Botulism in non-ruminants in Brazil
}

\author{
Botulismo em não ruminantes no Brasil
}

\section{Carlos Augusto de Oliveira Júnior ${ }^{\mathrm{I}}$ Rodrigo Otávio Silveira Silva ${ }^{\mathrm{I}^{*}}$ Roberio Gomes Olinda ${ }^{\text {II }}$ Francisco Carlos Faria LobatoI}

\section{- REVIEW -}

\section{ABSTRACT}

Botulism is an intoxication caused by the ingestion of neurotoxins secreted by Clostridium botulinum and characterized by progressive flaccid symmetrical paralysis. Among non-ruminant animals, avian species and dogs are the most commonly affected by botulism, while horses and pigs are less-commonly diagnosed with the disease. Despite the importance of this disease in animals, the Brazilian literature only includes case studies and outbreak descriptions. The aim of this study was to review the main features and to provide recent data on the occurrence of botulism in non-ruminants in Brazil.

Key words: flaccid paralysis, Clostridium botulinum, avian, dogs, horses, pigs.

\section{RESUMO}

O botulismo é uma intoxicação causada pela ingestão das neurotoxinas secretadas por Clostridium botulinum e caracterizada por uma paralisia flácida simétrica progressiva. Entre os animais não ruminantes, aves e cães são os mais comumente afetados, enquanto equinos e suínos são esporadicamente diagnosticados com a doença. Apesar da reconhecida importância dessa doença nos animais, a literatura brasileira baseia-se apenas em relatos de casos e descrições de surtos. O presente trabalho tem como objetivo revisar a ocorrência e principais característicasdo botulismo em animais não ruminantes no Brasil.

Palavras-chave: paralisia flácida, Clostridium botulinum, aves, cães, equinos, suínos.

\section{INTRODUCTION}

Botulism is an intoxication (foodborne disease - ingestion of pre-formed toxins) that affects humans and several animal species. Although less common, the disease can also occur when the microorganism grows and produces its neurotoxins in wounds (wound botulism) or in gut (intestinal botulism). The causative agent is Clostridium botulinum, a Gram-positive rod-shaped and strictly anaerobic bacterium which can be classified into eight types (A, B, C, D, E, F, G and H). Types C and $\mathrm{D}$ are commonly responsible for botulism in animals, with few cases being caused by the remaining types (LOBATO et al., 2013).

Botulinum neurotoxins are the strongest known microbial toxins. Following the ingestion, the botulinum toxins resist to proteolytic degradation in the gastrointestinal tract, are absorbed by the intestinal mucosa, and act on neuromuscular junctions preventing the release of acetylcholine, an excitatory neurotransmitter (AOKI et al., 2010). This release results in the inability to perform muscle contraction, leading to the characteristic ascending flaccid symmetrical paralysis but with unchanged consciousness or mental status (LOBATO et al., 2013).

In Brazil, botulism cases are extremely common in ruminants, birds and $\operatorname{dog} s$, and have also been described in other species (CUBAS, 1996; COELHO et al., 2000; RAYMUNDO et al., 2012a). In spite of the known importance of botulism in animals and the typical differences of the disease between species, the Brazilian literature is limited to case studies and outbreak descriptions. Therefore,

\footnotetext{
'Escola de Veterinária, Universidade Federal de Minas Gerais (UFMG), Avenida Antônio Carlos, 6627, 31270-901, Belo Horizonte, MG, Brasil. E-mail: rodrigo.otaviosilva@gmail.com. *Corresponding author.

"Departamento de Ciências Animais, Universidade Federal Rural do Semi-Árido (UFERSA), Mossoró, RN, Brasil. Received 04.15.16 Approved 07.05.16 Returned by the author 09.22.16 CR-2016-0394.R2
} 
a review that clarifies the clinical, pathological and epidemiological characteristics of botulism in animals in Brazil is essential. We recently reviewed the literature of botulism in ruminants (SILVA et al., 2016). Thus, the aim of this study was to review the characteristics and to provide recent data on botulism occurrence in non-ruminant animals in Brazil. The following databases were used in the present study: NCBI, SciELO, Scopus, Web of Science, Capes Thesis Library <capes.gov.br $>$ and Google Scholar.

\section{Botulism in birds}

Clostridium botulinum type $\mathrm{C}$ is the main organism responsible for botulism cases in birds, but types A and E can also affect them, although rarely (WOBESER, 1997). Botulism in birds was first reported in 1918 in the United States (DICKSON, 1918). In Brazil, the first cases were confirmed in chickens and ducks from Rio de Janeiro by BRADA et al. (1971). Botulism has since been reported for various bird species in Brazil including geese and garganey, and highmortality outbreaks have been reported in turkeys, guinea fowl, broiler chickens, ducks, and wild birds kept in captivity (SCHOKEN-ITURRINO et al., 1985; PIGATTO et al., 2007; COELHO et al., 2007; LOBATO et al., 2008; SILVA et al., 2008; LOBATO et al., 2009; RAYMUNDO et al., 2012b; ALVES et al., 2013; OLINDA et al., 2016). The main outbreaks of botulism in avian species in Brazil are summarized in table 1. Although more common in aquatic birds, large botulism outbreaks can occur on commercial broiler farms, especially when there is a poor mortality removal, which leads to cannibalism of decomposing carcasses (SCHOCKEN-ITURRINO, et al., 1985; PIGATTO et al., 2007; SATO et al., 2016).

Table 1 - Main reported botulism outbreaks in non-ruminants in Brazil (1970 to 2016).

\begin{tabular}{|c|c|c|c|c|c|c|}
\hline Year & State $^{b}$ & Species affected & $\begin{array}{l}\text { Number of } \\
\text { affected (at risk) }\end{array}$ & $\begin{array}{l}\text { Lethality } \\
(\%)\end{array}$ & $\begin{array}{l}\text { Probable source of } \\
\text { toxins }\end{array}$ & Reference \\
\hline 1970 & RJ & Chickens and ducks & $\mathrm{N} / \mathrm{U}$ & $\mathrm{N} / \mathrm{U}$ & $\mathrm{N} / \mathrm{U}$ & $\begin{array}{l}\text { BRADA et al. } \\
(1971)\end{array}$ \\
\hline 1985 & SP & Broiler chicken & $12,000(80,000)$ & $\mathrm{N} / \mathrm{U}$ & Carcasses & $\begin{array}{l}\text { SCHOCKEN- } \\
\text { ITURRINO et al. } \\
(1985)\end{array}$ \\
\hline 2000 & $\mathrm{GO}$ & Horses & $7(\mathrm{~N} / \mathrm{U})$ & 100 & Contaminated hay & $\begin{array}{l}\text { COELHO et al. } \\
(2000)\end{array}$ \\
\hline $2002-2009^{a}$ & $\mathrm{RS}$ & Pigs & $19(75)$ & 68,4 & Restaurante leftover & $\begin{array}{l}\text { RAYMUNDO et } \\
\text { al. }(2012 a)\end{array}$ \\
\hline $2002-2009^{a}$ & RS & Pigs & 2 & 100 & Restaurante leftover & $\begin{array}{l}\text { RAYMUNDO et } \\
\text { al. }(2012 a)\end{array}$ \\
\hline $2002-2009^{\mathrm{a}}$ & $\mathrm{RS}$ & Pigs & $18(70)$ & 83,3 & Restaurante leftover & $\begin{array}{l}\text { RAYMUNDO et } \\
\text { al. }(2012 a)\end{array}$ \\
\hline $2002-2009^{\mathrm{a}}$ & $\mathrm{RS}$ & Pigs & $4(30)$ & 100 & Restaurante leftover & $\begin{array}{l}\text { RAYMUNDO et } \\
\text { al. }(2012 a)\end{array}$ \\
\hline $2002-2009^{a}$ & RS & Pigs & $7(25)$ & 85,7 & Restaurante leftover & $\begin{array}{l}\text { RAYMUNDO et } \\
\text { al. }(2012 a)\end{array}$ \\
\hline 2005 & SP & Broiler chickens & 3,000 & - & $\mathrm{N} / \mathrm{U}$ & $\begin{array}{l}\text { PIGATTO et al. } \\
(2007)\end{array}$ \\
\hline 2009 & MG & Turkeys & $29(29)$ & 100 & Fly larvae & $\begin{array}{l}\text { LOBATO et al. } \\
(2009)\end{array}$ \\
\hline 2009 & ES & Chickens & $144(150)$ & 100 & $\mathrm{~N} / \mathrm{U}$ & $\begin{array}{l}\text { ALVES et al. } \\
(2013)\end{array}$ \\
\hline 2012 & $\mathrm{RS}$ & $\begin{array}{l}\text { Black-necked swans } \\
\text { (Cygnus melancoryphus) } \\
\text { and Muscovy duck } \\
\text { (Cairinamoschata) }\end{array}$ & $14(100)$ & 100 & Fly larvae & $\begin{array}{l}\text { RAYMUNDO et } \\
\text { al. }(2012 b)\end{array}$ \\
\hline 2016 & $\mathrm{RN}$ & $\begin{array}{l}\text { Chikens, ducks and } \\
\text { helmeted guinea fowl }\end{array}$ & $80(80)$ & 100 & $\mathrm{~N} / \mathrm{U}$ & $\begin{array}{l}\text { OLINDA et al. } \\
(2016)\end{array}$ \\
\hline
\end{tabular}

N/U - Not reported or unknown; ${ }^{a}$ - The date was not precisely reported; ${ }^{\text {b }}$ - RJ - Rio de Janeiro, SP - São Paulo, GO - Goiás, RS - Rio Grande do Sul, MG - Minas Gerais, ES - Espírito Santo, RN - Rio Grande do Norte. 
There are several possible sources of intoxication by botulinum toxin for birds, including rotting food, drinking troughs containing fecal matter, and puddles and lagoons with stagnant water, especially during the dry season, when toxins become more concentrated in these water bodies (ALVES et al., 2013; LOBATO et al., 2013; ANZA et al., 2016). Fly larvae (maggots) present in cadavers and other decomposing materials constitute another important source of intoxication. Fly larvae develop in these substrates, and because they are resistant to botulinum toxin, they concentrate it in their tissues. When birds ingest these larvae, they become intoxicated and develop botulism, commonly resulting in their death, and their subsequently becoming additional decomposing material for the potential development of larvae, closing the cycle (TAKEDA et al., 2006). This source of intoxication is extremely important, especially in countries with temperate climates where this cycle commonly culminates in seasonal outbreaks with extremely highmortality ratesin wildbirds (EVELSIZER et al., 2010; ANZA et al., 2016).

In Brazil, although reports of this type of outbreak in wildbirds are rare, the importance of fly larvae as sources of intoxication cannot be ignored (CUBAS, 1996). LOBATO et al. (2009) reported a botulism outbreak in an extensive turkey farm resulting in $100 \%$ mortality, in which fly larvae present in a composting area served as the intoxication source (Table 1). It should be noted that it is still common for researchers to report some difficulties in confirming the source of botulinum toxins in bird intoxications, and many reports in Brazil only hypothesize the probable origin of the intoxication (BRADA et al., 1971; PITAGATTO et al., 2007; LOBATO et al., 2009; ALVES et al., 2013; OLINDA et al., 2016). Although much less common, intestinal and wound botulism can also occur in avian species (PECELEUNAS et al., 1999; TRAMPEL et al., 2005). Anyway, there is no description of these types of botulism in avian species in Brazil so far.

The period of incubation of botulism in birds varies from a few hours up to two days following toxin ingestion. Depending on the severity of the intoxication, different clinical presentations may be observed in birds. In mild cases, movement instability and sleepiness are observed, and most animals are completely recovered after 4 days. In more severe cases, extreme prostration and flaccid paralysis of the leg, wing and neckmuscles may manifest. Animals are commonly found with drooping wings, neck and head on the ground, partially closed eyelids and ruffled plumage, and easily plucked feathers. However, the mental status remains unchanged, and death results from cardiopulmonary arrest (BRADA et al., 1971; LOBATO et al., 2009; OLINDA et al., 2016).

Botulism in dogs

Botulism in dogs was confirmed for the first time in 1978 in the United States in an outbreak in a colony of American foxhounds (BARSANTI et al., 1978). Only $\boldsymbol{C}$. botulinum type $\mathrm{C}$ has been implicated in botulism in dogs, but recently a case of type B botulism in a pregnant bitch was described (LAMOUREUX et al., 2015). The two main toxin sources reported in cases of botulism in dogs in Brazil are carcasses and inadequately discarded rotting food (MONEGO et al., 2006; DALMOLIN et al., 2008; SALVARANI et al., 2008; SILVA et al., 2008; MOURA et al., 2014). There are few data on botulism prevalence in dogs in Brazil. In a retrospective study at Veterinary Hospital of Universidade Federal de Santa Maria (UFSM), only 2 cases of botulism were confirmed among all necropsied dogs between 1965 and 2004 (FIGHERA et al., 2008). Conversely, a recent one-year survey performed at the Veterinary Hospital of the University of Cuiabá (Universidade de Cuiabá) revealed that more than $40 \%$ of neuromuscular disorder cases in dogs were due to botulism (STUCCHI et al., 2013). So far, this disease is extremely rare in cats and there are no case reports in Brazil.

Similar to the other species, the severity of clinical signs and prognosis of botulism cases in dogs are dose-dependent. The average period of disease incubation is 12 to 24 hours, but it may reach up to five days following toxin ingestion. Depending on the severity of the intoxication, dogs present symptoms progressing from limb instability and weakness, starting at the pelvic limbs, to the classic generalized paralysis with unchanged mental status and pain perception. In dogs with mild intoxication the tail tonus may remain normal, which contrasts with what is observed in bovine (MOURA et al., 2014; LAMOUREUX et al., 2015). Other possible clinical signs are dehydration, inappetence, fecal and urinary retention, megaesophagus, and bronchopneumonia resulting from immobility (SILVA et al., 2008; URIARTE et al., 2010; MOURA et al., 2014).

Other non-ruminants species

Horses are very susceptible to C. botulinum neurotoxins and types $\mathrm{A}, \mathrm{B}$ and $\mathrm{C}$ are the most common types of botulism in these animals (JOHNSON et al., 2010). Despite the high susceptibility of equine to botulinum toxin, there is only one report of botulism 
in horses in Brazil (COELHO et al., 2000). In this case, seven Arabian mares showed muscular tremors and respiratory difficulties followed by coma and death. Authors hypothesized that hay contaminated with a rat carcass was responsible for the outbreak (COELHO et al., 2000).

In other countries, potential sources of toxins include hay or feed contaminated with carrion and rotted vegetation or forage (SCHOENBAUM et al., 2000). Foals (and eventually adults) may also develop intestinal botulism, a condition also called "shaker foal syndrome", where the $\boldsymbol{C}$. botulinum produce toxin within the gastrointestinal tract. Although rare, wound botulism can also occur in equids (GALEY, 2001; FREY et al., 2007).

Clostridium botulinum has been also associated with the "Equine grass sickness" (EGS), a nervous disease of unknown etiology that is characterized by a severe neuronal degeneration and widespread neuronal loss in both the enteric and autonomic nervous systems (dysautonomia) (HUNTER et al., 1999; WYLIE \& PROUDMAN, 2009). Anyway, the link between EGS and botulism is still not fully understood and some authors hypothesize they are completely distinct diseases, being linked only by the need of differential diagnosis (BOHNEL et al., 2003).

Typical progressive flaccid paralysis is the most common sign of botulism in equine, with a regular muscular weakness that rapidly progresses to lateral recumbency with paresis of the tongue, throat and lips. Even while recumbent, the animals commonly stay alert and interested in eating and drinking (SCHOENBAUM et al., 2000). Dysphagia may also be present; although, it is not a consistent finding (GALEY, 2001). Once equine are very susceptible to $\boldsymbol{C}$. botulinum neurotoxins, the disease should also be considered in cases where only weakness or intolerance to exercise is seen.

It is believed that botulism occurs sporadically in equine in Brazil but its diagnosis might be underestimated mainly due to nonspecific clinical signs presented by horses with mild intoxication, including weakness and exercise intolerance. Presumptive diagnosis of intestinal botulism is particularly difficult once the history of contaminated food ingestion is commonly absent in these cases (SMITH \& SUGIYAMA, 1988). In light of this, clinical specimens of horses are rarely tested for the presence of botulinum toxins. Laboratory diagnosis of animals with suggestive clinical signs should be encouraged among clinicians for a better understanding of the real importance of botulism in equine in Brazil.
Botulism is rare in swine and only three cases have been reported so far, one of them in Brazil (BEIERS \& SIMMONS, 1967; DOUTRE, 1967; RAYMUNDO et al., 2012b). In this case, the animals were fed with food residues originating from restaurant and hotel kitchens that were stored at room temperature, in barrels and offered to the animals without a prior thermal treatment. Animals of different age groups showed flaccid paralysis, anorexia, weakness, locomotion difficulties followed by lateral recumbency (RAYMUNDO et al., 2012b). In all these three previously reported cases, including the one in Brazil, C. botulinum toxin type $\mathrm{C}$ was detected (BEIERS \& SIMMONS, 1967; DOUTRE, 1967; RAYMUNDO et al., 2012b).

\section{Diagnosis}

The presumptive diagnosis of botulism in animals is based on the combination of history and characteristic clinical signs. Typically, no significant changes are observed at post mortem evaluation, but the presence of fly larvae in the stomach of avian species may indicate botulism. In dogs, history of contact with carcasses, including rodents and birds, rotting food and garbage are very common. For horses, botulism should be considered in cases where weakness, paralysis, or even intolerance to exercise occurs. Laboratory confirmation is essential and is based on the detection and identification of botulinum toxin(s) in clinical specimens using serum neutralization tests in mice (GALEY, 2001; LOBATO et al., 2013).

When working with a group of animals, it is essential to collect material from those presenting shorter incubation times and acute disease courses, indicating higher ingestion of botulinum toxin. Animals that died more than three hours before collection should be avoided since substantial toxin degradation could occur and undermine the diagnosis (LOBATO et al., 2013).

Considering that most avian species are highly resistant to botulinum toxin (SMITH, 1980; SMITH, 1983), diagnosis in these animals should be performed using, in increasing order of preference, blood serum and chemical and mechanical stomach contents (LOBATO et al., 2009; ALVES et al., 2013). In dogs, which are less resistant than birds but less susceptible than equine and swine, the collection of blood serum, stomach contents or vomit (if the ingestion was recent) and intestinal contents is recommended (SILVA et al., 2008). In all other non-ruminant species, stomach and intestinal content and liver fragments should be collected (LOBATO et al., 2013). 
Clinical samples for detection of botulinum toxin should be submitted to the laboratory under refrigeration or frozen. At least $2 \mathrm{~mL}$ of blood serum and around $50 \mathrm{~g}$ of liver fragments and duodenal contents should be submitted. It is important to note that the stomach and intestinal contents should be drained and sent in vials. Sending the contents inside the organs may increase the chance of false-negative results, as proteases may degrade the toxins. Food and water suspected of being intoxication sources can also be sent. Currently, the National Agriculture Laboratory of Pedro Leopoldo (Laboratório Nacional Agropecuário de Pedro Leopoldo), in the state of Minas Gerais - Brazil, performs free analyses of botulinum toxins in animal and food samples by serum neutralization test in mice, considered the gold standard method to diagnose botulism in animals.

Paralytic rabies should be the main differential diagnosis in dogs, equine and pigs. Clinicians should be aware that the mental status remains unchanged in botulism; whereas, rabies causes some behavioral abnormalities (LOBATO et al., 2013; MEGID et al., 2016). Other differential diagnoses in dogs include acute polyradiculoneuritis and myasthenic disorders, such as tick paralysis, a disease caused by neurotoxins secreted by ticks belonging to the genera Ixodes and Dermacentor (BORS et al., 1988; NELSON \& COUTO, 2001; ALVES et al., 2013). In avian species, arsenic poisoning and Newcastle disease should be considered, while Aujeszky's disease is also an important differential diagnosis for swine (MEGID et al., 2016).

Treatment

The treatment of botulism in dogs and equine is based on support treatment and administration of antitoxins, which are commercially available in Brazil. Antitoxins should be administered early, as they only act on free-circulating toxin, having no effect on toxin already fixed to neuromuscular junctions (GREENE, 1998; NELSON \& COUTO, 2001). Support treatment is essential and mainly includes hydration, ventilation, management of dysphagia and urinary retention, and constant repositioning to avoid decubitus ulcers. Fecal retention is common, and the administration of laxatives and performance of enemas in cases of recent intoxication may also help to eliminate un absorbed toxins present in the gastrointestinal tract (SILVA et al., 2008).

Because of the longer disease course in birds, administration of antitoxins with or without concomitant immunization can increase survival rates, especially in aquatic birds (MARTINEZ
\& WOBESER, 1999; UNITED STATES, 2001). However, especially on commercial rearing farms, treatment becomes nonviable due to the large number of affected animals, the high cost, and the long recovery of the animal (ALVES et al., 2013).

Once the toxin cleaves proteins responsible for the release of neurotransmitters in neuromuscular junctions, recovery takes place as new parallel synapses are formed. Recovery of mildly to moderately affected animals takes between one and three weeks, whereas, in more severe cases, the prognosis is not favorable, with occurrence of death by pulmonary arrest or secondary infections, particularly pulmonary and cystic ones (FARROW et al., 1983; BORS et al., 1988; SILVA et al., 2008; MOURA et al., 2014). Lethality of botulism in dogs and birds can be considered low when compared to other domestic species including equids, bovine and swine (LOBATO et al., 2013).

Prevention and control

Studies on botulism prevention in birds through vaccination with $\boldsymbol{C}$. botulinum toxoids have been reported in countries where large outbreaks in free-living animals are common (ROCKE et al., 2000; ARIMITSU et al., 2004). However, there are still no commercial vaccines for birds in Brazil. Therefore, animal access to potential intoxication sources should be prevented, especially composting areas and areas with carcasses or other types of decomposing organic matter. Lagoons and areas with stagnant water should be cleaned, especially during the dry season, collecting as much decomposing organic matter as possible, especially carcasses (LOBATO et al., 2009).

In Europe and the United States, reports of botulism in equine have increased in recent years due to the growing popularity of haylage feeding. In light of this, vaccination has been used in some endemic areas (GALEY, 2001; FREY et al., 2007). In Brazil, the routine vaccination of dogs, equids or swine would hardly be justifiable, as cases of botulism in these species are sporadic. In addition, there is no botulism toxoid commercially available in Brazil for prevention of the disease in non-ruminants species. Thus, botulism should be controlled by preventing animals from accessing potential sources of botulinum toxin, especially decomposing carcasses and garbage containing decomposing food (SILVA et al., 2008). A special attention should be given during preparation and stocking of hay, silage or any feed to avoid accidental incorporation of animal carcasses, especially of birds and rodents (ANNIBALLI et al., 2013; LOBATO et al., 2013). 


\section{ACKNOWLEDGEMENTS}

The authors are thankful for the financial support from Fundação de Amparo à pesquisa do Estado de Minas Gerais (FAPEMIG) (APQ-02304-13), Coordenação de Aperfeiçoamento de Pessoal de Nível Superior (CAPES/Proex) and Conselho Nacional de Desenvolvimento Científico e Tecnológico (CNPq).

\section{REFERENCES}

ALVES, G.G. et al. Outbreak of type C botulism in chickens in Pancas city, Espírito Santo state, Brazil. Semina Ciência Agrárias, v.34, n.1, p.355-358, 2013. Available from $<$ http://www.uel.br/revistas/uel/index.php/semagrarias/ article/view/10247/pdf $>$. Accessed: Jan. 10, 2016. doi: 10.5433/1679-0359.2013v34n1p355.

ANNIBALLI, F. et al. Management of animal botulism outbreaks: from clinical suspicion to practical countermeasures to prevent or minimize outbreaks. Biosecurity and Bioterrorism, v.11, S1, S191-S199, 2013.

ANZA, I. et al. Differences in the vulnerability of waterbird species to botulism outbreaks in Mediterranean wetlands: an assessment of ecological and physiological factors. Applied and Environmental Microbiology, AEM.00119-16, 2016. Available from: <https://www.ncbi.nlm.nih.gov/pubmed/27016572>. Accessed: Jan. 10, 2016

AOKI, K.R. et al. Mode of action of botulinum neurotoxins: current vaccination strategies and molecular immune recognition. Critical reviews in immunology, v.30, p.167-187, 2010. Available from: $<$ http://www.ncbi.nlm.nih.gov/pubmed/20370628>. Accessed Jan. 10, 2016.

ARIMITSU, $H$. et al. Vaccination with recombinant whole heavy chain fragments of Clostridium botulinum Type C and D neurotoxins. Clinical and Diagnostic Laboratory Immunology, v.11, n.3, p.496-502, 2004. Available from: <http://www.ncbi. nlm.nih.gov/pubmed/15138174>. Accessed: Jan. 10, 2016. doi: 10.1128/CDLI.11.3.496-502.2004

BARSANTI, J.A. et al. Type C botulism in American foxhounds. Journal of the American Veterinary Medical Association, v.172, p.809-813, 1978. Available from: <http:/www.ncbi.nlm. nih.gov/pubmed/640944>. Accessed: Jan. 10, 2016.

BEIERS, P.R.; SIMMONS, G.C. Botulism in pigs. Australian Veterinary Journal, v.43, n.7, p.270-271, 1967. Available from: $<$ https://www.ncbi.nlm.nih.gov/pubmed/6069702>. Accessed: Jan. 10, 2016

BÖHNEL, H.et al. Two cases of equine grass sickness with evidence for soil-borne origin involving botulinum neurotoxin. Journal of veterinary medicine. $B$, Infectious diseases and veterinary public health, v.50, n.4, p.178-182, 2003.

BORS, M. et al. Neuromuscular disease in a dog. Cornell Veterinarian, v.78, p.339-345, 1988. Available from: <http://www. ncbi.nlm.nih.gov/pubmed/3168469>. Accessed: Jan. 10, 2016.

BRADA, W. et al. Botulismo em aves no estado do Rio de Janeiro. Pesquisa Agropecuária Brasileira, v.6, p.27-32, 1971. Available from: <http://seer.sct.embrapa.br/index.php/pab/article/ view/17725>. Accessed: Jan. 10, 2016.
COELHO, H.E. et al. Botulism in domestic birds (Gallus gallus domesticus) - Case Report. Arquivo Ciência Veterinária e Zoologia da Unipar, v.10,p.125-128, 2007. Available from: $<$ http:// revistas.bvs-vet.org.br/acvzunipar/article/view/13696/14552>. Accessed: Jan. 10, 2015

COELHO, H.E. et al. Surto de botulismo tipo C em equinos. Veterinária Notícias, v.6, p.99-103, 2000.

CUBAS, Z.S. Special challenges of maintaining wild animals in captivity in South America. Revue Scientifiqueet Technique feL Office International fes Epizooties, v.15, p.267-287, 1996. Available from: <http://www.oie.int/doc/ged/d9040.pdf $>$. Accessed: Jan. 10, 2016.

DALMOLIN, F. et al. Botulismo em cão - Relato de três casos no município de Uruguaiana, Rio Grande do Sul. In: CONBRAVET - CONGRESSO BRASILEIRO DE MEDICINA VETERINÁRIA, 2008, Gramado, RS. V.35. Available from: <http://www.sovergs. com.br/conbravet2008/anais/cd/resumos/R0191-2.pdf $>$. Accessed: Jan. 10, 2016

DICKSON, E.C. Botulism: a case of limber-neck in chickens. Journal of American Veterinary Medical Association, v.50, p.612-613, 1918. Available from: <http://archinte.jamanetwork. com/article.aspx?articleid $=654271>$. Accessed: Jan. 10, 2016. doi: 10.1001/archinte.1918.00090150077005.

DOUTRE, M.P. 1st case of beta $\mathrm{C}$ botulism in swine in Senegal. Revue d'élevageet de Médecine Vétérinaire des Pays Tropicaux, v.20, n.2, p.251-253, 1967. Available from: <https://www.ncbi. nlm.nih.gov/pubmed/4881104>. Accessed: Jan. 10, 2016

EVELSIZER, D.D. et al. Survival of radio-marked mallards in relation to management of avian botulism. Journal of Wildlife Diseases, v.46, n.3, p.864-877, 2010. Available from: <http://www. ncbi.nlm.nih.gov/pubmed/20688692>. Accessed: Jan. 10, 2016. doi: 10.7589/0090-3558-46.3.864

FARROW, B.R.H. et al. Type C botulism in young dogs. Australian Veterinary Journal, v.60, n.12, p.374-377, 1983. Available from: $<$ http://www.ncbi.nlm.nih.gov/pubmed/6365067>. Accessed: Jan. $10,2015$.

FIGHERA, R.A. et al. Causes of death and reasons for euthanasia in dogs from the midland region of Midwest of Rio Grande do Sul State, Brazil (1965-2004). Pesquisa Veterinária Brasileira, v.28, n.4, p.223-230, 2008. Available from: <http://www.scielo.br/pdf/ pvb/v28n4/v28n4a05.pdf>. Accessed: Mar. 10, 2016.

FREY, J.Alternative vaccination against equine botulism(BoNT/C). Equine Veterinary Journal v.39, p.516-20, 2007. Available from: $<$ http://www.ncbi.nlm.nih.gov/pubmed/18065309>. Accessed: Jan. 10, 2016. doi: 10.2746/042516407X236550.

GALEY, F.D. Botulism in the horse. Veterinary Clinics of North America: Equine Practice, v.17, p. 579-588, 2001. Available from: <http://www.ncbi.nlm.nih.gov/pubmed/11780288>. Accessed: Jan. 10, 2016.

GREENE, C.E. Infectious diseases of the dog and cat. 2.ed. Philadelphia: Saunders, 1998. 421p.

HUNTER, L.C. et al. The association of Clostridium botulinum type $\mathrm{C}$ with equine grass sickness: a toxicoinfection? Equine Veterinary Journal, v.31, p.492-499, 1999. Available from: 
<http://www.ncbi.nlm.nih.gov/pubmed/10596931>. Accessed: Jan. 10, 2016. doi: 10.1111/j.2042-3306.1999.tb03857.x.

JOHNSON,A.L. et al. Type Abotulism in horses in the United States: a review of the past ten years (1998-2008). Journal of Veterinary Diagnostic Investigation, v.22, p.165-173, 2010. Available from: $<$ http://www.ncbi.nlm.nih.gov/pubmed/20224073>. Accessed: Jan. 10, 2016. doi: 10.1177/104063871002200201.

LAMOUREUX, A. et al. A case of type B botulism in a pregnant bitch. Journal of Small Animal Practice, v.56, p.348-350, 2015. Available from: <https://www.ncbi.nlm.nih.gov/pubmed/25362862>. Accessed: Jan. 10, 2016. doi: 10.1111/jsap.12290.

LOBATO, F.C.F. et al. Type C botulism in turkeys in Minas Gerais, Brazil. Ciência Rural, v.39, n.1, p.272-274, 2009. Available from: $<$ http://www.scielo.br/scielo.php?pid=S010384782009000100047\&script $=$ sci arttext $>$. Accessed: Jan. 10, 2016. doi: 10.1590/S0103-84782008005000048.

LOBATO, F.C.F. et al. Clostridioses dos animais de produção. Veterinária e Zootecnia, v.20, p.29-48, 2013. Available from $<$ http://www.fmvz.unesp.br/rvz/index.php/rvz/article/view/651>. Accessed: Jan. 10, 2016.

LOBATO, F.C.F. et al. Type C botulism in a goose at Minas Gerais, Brazil. Ciência Rural, v.38, n.4, p.1179-1180. 2008. Available from: <http://dx.doi.org/10.1590/S0103-84782008000400047> Accessed: Jan. 10, 2016. doi: 10.1590/S0103-84782008000400047.

MARTINEZ, R.; WOBESER, G. Immunization of ducks for type $\mathrm{C}$ botulism. Journal of Wildlife Diseases, v.35, n.4, p.710-715, 1999. Available from: <http://www.bioone.org/doi/ pdf/10.7589/0090-3558-35.4.710>. Accessed: Sept. 10, 2015. doi: $10.7589 / 0090-3558-35.4 .710$

MEGID, J. et al. Doenças Infecciosas em animais de produção e companhia. Rio de Janeiro: Roca, 2016. 1294p.

MONEGO, F. et al. Diagnóstico de Clostridium Botulinum Tipo C em cão - Relato de caso. Veterinária Notícias, v.12, p.79-81, 2006. Available from: <http://www.seer.ufu.br/index.php/vetnot/ article/view/18815>. Accessed: Jan. 10, 2016.

MOURA, J.B. et al. Botulismo em cães - relato de dez casos. Clínica Veterinária, v.29, p.46-51, 2014.

OLINDA, R.G. et al. Outbreak of type C botulism in poultry in the semiarid Northeast, Brazil. Revista Brasileira de Ciência Veterinária, v.22, p.157-159, 2016. Available from: <http://doi. editoracubo.com.br/10.4322/rbcv.2016.006>. Accessed: Jan. 10, 2016. doi: $10.4322 /$ rbcv.2016.006.

PECELEUNAS, K.S. et al. Botulism in chickens associated with elevated iron levels. Avian Diseases, v.43. n.4, p.783-787, 1999. Available from: $<$ http://www.ncbi.nlm.nih.gov/pubmed/10611996>. Accessed: Jan. 10, 2016.

PIGATTO, C.P. et al. Intoxicação natural por Clostridium botulinum tipo $\mathrm{C}$ em grupo de aves domésticas. Archives of Veterinary Science, v.12, n.2, p.12-16, 2007. Available from: $<$ http://ojs.c3sl.ufpr.br/ojs-2.2.4/index.php/veterinary/article/ view/9903>. Accessed: Jan. 10, 2016.

RAYMUNDO, D.L. et al. Outbreak of type C botulism in captive wild birds. Journal of Zoo and Wildlife Medicine, v.43, p.388-
390, 2012b. Available from: <http://www.ncbi.nlm.nih.gov/ pubmed/22779246>. Accessed: Jan. 10, 2016.

RAYMUNDO, D.L. et al. Type C botulism in swine fed on restaurant waste. Pesquisa Veterinária Brasileira, v.32, p.1145-1147, 2012a. Available from: $<$ http://www.scielo.br/scielo.php?script=sci arttext\&pid=S0100-736X2012001100012>. Accessed: Jan. 10, 2016. doi: 10.1590/S0100-736X2012001100012.

ROCKE, T.E. et al. Efficacy of a type $\mathrm{C}$ botulism vaccine in green-winged teal. Journal of Wildlife Disease, v.36, n.3, p.489-493, 2000. Available from: <http://www.ncbi.nlm.nih.gov/ pubmed/10941734>. Accessed: Jan. 10, 2016.

SALVARANI, R.S. et al. Botulismo em cães - Relato de caso. Revista Científica Eletônica de Medicina Veterinária, v.10 p. 1-5, 2008.

SATO, Y. et al. Outbreak of Type C botulism in commercial layer chickens. Avian Diseases, v.60, p.90-94, 2016. Available from: $<$ https://www.ncbi.nlm.nih.gov/pubmed/26953952>. Accessed: Apr. 10, 2016. doi: 10.1637/11293-100415-Case.1.

SCHOCKEN ITURRINO, R.P. et al. An outbreak of type C botulism in broiler chickens in São Paulo State, Brazil. Revista de Microbiologia, v.16, p.31-35, 1985 .

SCHOENBAUM, M.A. et al. An outbreak of type C botulism in 12 horses and a mule. Journal of the American Veterinary Medical Association. v.217, p.365-368, 2000. Available from: <http://www. ncbi.nlm.nih.gov/pubmed/10935041>. Accessed: Jan. 10, 2016.

SILVA, R.O.S. et al. Botulism in ruminants in Brazil: a review. Ciência Rural, v.46, p. 1411-1417, 2016. Available from: <http:// dx.doi.org/10.1590/0103-8478cr20151486>. Accessed: Jan. 10 2016. doi: 10.1590/0103-8478cr20151486.

SILVA, R.O.S. et al. Type C botulism in a dog. Ciência Veterinária nos Trópicos, v.11, p.86-89, 2008. Available from: $<$ http://www.rcvt.org.br/volume11_2_3/pag_86_a_89.pdf $>$. Accessed: Jan. 10, 2016.

SMITH, G.R. Concentrations of toxin in the serum of waterfowl with botulism. Veterinary Record, v.107, p.513, 1980. Available from: <http://veterinaryrecord.bmj.com/content/107/22/513>. Accessed: Jan. 10, 2016.

SMITH, G.R. Diagnosis of botulism in waterbirds. Veterinary Record, v.112, p.457-458, 1983.

SMITH, L.D.S.; SUGIYAMA, H. Botulism: the organism, its toxins, the disease. 2.ed. Springfield: Charles Thomas, 1988.171p.

STUCCHI, C. et al. Avoiding misdiagnosis in patients with acute paresis/paralysis with emphasis on botulism. Revista de Ciências Agroveterinárias, v.13, p.3-4, 2013. Available from: $<$ http://revistas.udesc.br/index.php/agroveterinaria/article/ viewFile/5496/3724>. Accessed: Jan. 10, 2016.

TAKEDA, M. et al. Protective effect of botulinum C/D mosaic toxoid against avian botulism. Journal of Veterinary Medical Science, v.68, p.325-300, 2006. Available from: <http://www.ncbi. nlm.nih.gov/pubmed/16679722>. Accessed: Jan. 10, 2016.

TRAMPEL, D.W. et al. Toxicoinfectious botulism in commercial caponized chickens. Avian Diseases, v.49, p.301-333, 2005. 
UNITED STATES. U.S. Department of Interior; U.S Geological Survey. Field manual of wildlife diseases: general field procedures and diseases of birds. Biological Resources Division, 2001. 426p.

URIARTE, A.et al. Botulism in 2 urban dogs. Canadian Veterinary Journal, v.10, p.1139-1142, 2010. Available from: $<$ https://www.ncbi.nlm.nih.gov/pubmed/21197207>. Accessed: Jan. 20, 2016.
WOBESER, G. Avian botulism - Another perspective. Journal of Wildlife Diseases, v.33, p.151-156, 1997. Available from: <http:// www.jwildlifedis.org/doi/abs/10.7589/0090-3558-33.2.181>. Accessed: Jan. 10, 2015. doi: 10.7589/0090-3558-33.2.181.

WYLIE, C.E.; PROUDMAN, C.J. Equine grass sickness: epidemiology, diagnosis, and global distribution. Veterinary Clinics of North America: Equine Practice, v.25, p.381-399, 2009. Accessed: Jan. 10, 2016. doi: 10.1016/j.cveq.2009.04.006. 